\title{
The Process of Teacher's Lesson Plan for Learning English through Google Classroom in the Senior High School
}

\author{
Ni Wayan Widya Arsini ${ }^{1 *}$, Dewa Komang Tantra ${ }^{2}$, G.A.P Suprianti ${ }^{3}$ (D
}

1,2,3 Ganesha University of Education, Singaraja, Indonesia

\section{A R T I C L E I N F O}

Article history:

Received October 18, 2021

Revised October 22, 2021

Accepted November 17, 2021

Available online December 25, 2021

Kata Kunci:

Rencana Pelajaran, Belajar Bahasa

Inggris, Google Classroom

Keywords:

Lesson Plan, Learning English, Google

Classroom

DOI:

http://dx.doi.org/10.23887/jpbi.v9i3.40 453

\section{A B S T R A C T}

During the pandemic, the education system in Indonesia was prepared and implemented through online learning media. Teachers are still lacking in detail in preparing appropriate learning plans for online learning. It results in learning activities not running optimally. English teachers must develop lesson plans based on standard rules in the curriculum. It is so that learning activities can run optimally. The objectives of this study are the process and difficulties faced by English teachers in preparing English lesson plans during a pandemic situation, where learning is carried out through Google Classroom. This research is a qualitative descriptive study with the subject of research being English teachers. Data was collected through a questionnaire regarding lesson plan simplification, which included learning objectives, materials, activities, media and sources, and assessment. The data obtained were analyzed descriptively and qualitatively. The results showed that the teacher fulfilled all the steps in the five aspects of the one-page lesson plan, which fulfilled the steps provided by the instrument. Meanwhile, in compiling the RPP for learning English through Google Classroom, the teacher found a problem: the learning objectives that included an audience. Research findings indicate that improvements are needed in learning and its implementation through online learning platforms.

This is an open-access article under the CC BY-SA license. Copyright (C) 2021 by Author. Published by Universitas Pendidikan Ganesha.

\begin{abstract}
A B S T R A $\boldsymbol{K}$
Di masa pandemi, sistem pendidikan di Indonesia disiapkan dan dilaksanakan melalui
A B S T R A K
Di masa pandemi, sistem pendidikan di Indonesia disiapkan dan dilaksanakan melalui pembelajaran yang sesuai untuk pembelajaran online. Hal tersebut mengakibatkan kegiatan pembelajaran tidak berjalan secara maksimal. Guru bahasa Inggris harus mengembangkan RPP berdasarkan aturan standar dalam kurikulum. Hal ini tujuan dari agar kegiatan pembelajaran dapat berjalan dengan optimal. Adapun Inggris dalam menyusun RPP bahasa Inggris pada saat situasi pandemi, dimana pembelajaran dilakukan melalui Google Classroom. Penelitian ini merupakan penelitian deskriptif kualitatif dengan subjek penelitian adalah guru bahasa Inggris. tujuan pembelajaran, materi, kegiatan, media dan sumber, serta penilaian. Data yang diperoleh dianalisis secara deskriptif dan kualitatif. Hasil penelitian menunjukkan bahwa guru memenuhi semua langkah dalam lima aspek RPP satu halaman, yang memenuhi langkah-langkah yang disediakan oleh instrumen. Sementara itu, dalam menemukan masalah: tujuan pembelajaran yang mengikutsertakan audiens. Temuan penelitian menunjukkan bahwa diperlukan perbaikan dalam pembelajaran dan implementasinya melalui platform pembelajaran online.

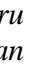


do face-to-face learning. Due to the pandemic, the education system in Indonesia is prepared and implemented through an online platform. Teachers and students do virtual learning by using online platforms such as Zoom, Google Meet, Google Classroom, Schoology, Webex, and so on (Mpungose, 2020; Santosa et al., 2020; Singh et al., 2020; Suhery et al., 2020).

Google Classroom is one of the platforms that is commonly used to facilitate online learning. The platform allows teachers and students to freely connect, collaborate, discuss, organize, and conduct the learning process. As Google Classroom can facilitate online learning, teachers and students can still conduct the learning process without the need of meeting face-to-face (Al-Maroof \& Al-Emran, 2018; Guswara, 2020; Kumar et al., 2020). Moreover, as the ones who manage the virtual classroom, teachers can make announcements, post, learning materials, and create assignments and quizzes for students to complete. These show that Google Classroom offers many benefits for both the educators and the students (Khalil, 2018; Kurniawati et al., 2019). However, since the current online class is implemented due to a pandemic situation, both the teachers and students face challenges in the implementation as it is quite new and change is just too sudden (Albashtawi et al., 2020; Amrina \& Sundari, 2021; Mahitsa \& Mahardini, 2020). To conduct EFL online learning, a lesson plan needs to be developed by teachers as a direction to all activities in the class (Albashtawi et al., 2020; Arief Eko Priyo Atmojo \& Nugroho, 2020; Nartiningrum, 2020). Based on the observation about the lesson plan made by the teacher, it was found that teacher still lack supporting details and the steps were still ambiguous. The English teachers have to prepare their lesson plans based on the standard rules in that curriculum (Atmojo \& Nugroho, 2020; Nugroho et al., 2021). In term of making effective lesson for online learning, all activity in the class has to be arranged purposefully. The lesson plan is essential to making an effective lesson in the current situation (Kubilinskiene \& Dagiene, 2010; Latifa, 2017; Mauliate et al., 2019). To accommodate effective lesson planning, the teachers should pay attention to five aspects related to the benchmark from Regulation of the Ministry of Education and Culture number 14 of 2019 concerning of simplification of Lesson Plan, such as learning objective, learning materials, learning activities, 4) learning media and source and, learning assessment (Iqbal et al., 2021; Raynesa, 2019; Utami et al., 2021). The five aspects are assumed to be appropriate for setting up English learning activities.

Some studies had been conducted investigating lesson plans and Google Classroom topics. Previous research aimed to know whether of lesson plan was made by the English teachers referring to curriculum 2013 or not and know the difficulties faced by the teachers when designing the lesson plan (Luciana, 2020; Sari, 2018; Susilowati et al., 2018). The result revealed that the lesson plan components did not reflect the curriculum. Further, the result also showed that the teachers faced difficulties as there were inadequate facilities and were still confused about the learning system in the curriculum 2013. Previous research conducted the study about lesson plans through behavioral objective theory. This study objected to the analysis of English teachers in preparing English learning lesson plans through behavioral objective theory. This study employs a descriptive qualitative method (Mauliate et al., 2019; Raynesa, 2019). The result of this study revealed that the objective statement is congruent with the goals of the curriculum 2013 lesson plan but still needs improvements to complete the three learning domains in the objective statement. The research studied teacher experiences on the use of Google Classroom, presenting how teachers perceived the platform as a learning media (Al-Maroof \& Al-Emran, 2018; Harjanto \& Sumarni, 2019; Kumar et al., 2020). The result indicates that the platform was used for managing students' tasks, organizing the classrooms, and accommodating student interaction. The teacher perceived the use of Google Classroom as very helpful to conduct their virtual classroom (Guswara, 2020). Different from the previous studies, this study will determine teachers' process in preparing English lesson plans through Google Classroom and will focus more on the five aspects of the lesson plan in senior high school. The setting of this study will be used at SMA Swasta Laboratorium Undiksha Singaraja. There was no previous study occurred regarding the preparation aspect of the lesson plan and also not a single study about the lesson plan was conducted in SMA Swasta Laboratorium Undiksha Singaraja. The objectives of this study are: the process and difficulties faced by English teachers in preparing English lesson plans during a pandemic situation, learning is done through Google Classroom. We hope that this pandemic situation will not hinder student learning.

\section{METHOD}

This research used descriptive qualitative research. The design was chosen with regards to the objectives of the study, which aimed at investigating the process and difficulties faced by the teachers in preparing an English lesson plan in the context of the COVID-19 pandemic. The research setting was SMA Swasta Laboratorium Undiksha Singaraja located in Singaraja, Buleleng district, Buleleng regency. The school was selected because it was one of the schools that suitable for the researcher to collect the data. It implemented the online learning process during the pandemic through the use of Google Classroom. Further, the research about lesson plans for learning English through Google Classroom is not yet identified. A set of data collection methods was used to gather all the data needed for this study. The instrument used to gather the data related to the process in preparing the lesson plans were made in accordance with the Surat Edaran Kementerian Pendidikan dan Kebudayaan Nomor 14 Tahun 
2019 tentang Penyederhaan Rencana Pelaksanaan Pembelajaran, which included five aspects. They were (1) learning objectives, (2) learning materials, (3) learning activities, (4) learning media and sources, and (5) learning assessment.

The data of difficulties encountered by the teacher in preparing lesson plans are collected by using a questionnaire. The questionnaire consists of 20 items of questions, which determine five aspects, such as difficulties in learning (1) objectives, (2) materials, (3) activities, (4) media and sources, and (5) assessment. To collect the data related to the process of preparing a lesson plan, the researcher went through several steps, such as collecting the finished lesson plans that had been developed by the teachers, giving the teachers the instrument used to investigate the process in preparing English lessons plans and asking them to complete the instrument, informing the teachers about the needs of reading the items in the instrument thoroughly and provide the complete and real process in making lesson plan, telling the teachers to reflect and assess the order of the steps in making lesson plans, and analyzing the data that had been collected. Similar to the process of collecting the first data, the research also performed several steps in collecting the data related to the difficulties faced by the teacher in preparing the English lesson plans. It includes collecting the finished lesson plans that had been developed by the teachers, handing the instrument regarding the difficulties in making a lesson plan to the teachers and asking them to complete it, suggesting the teacher read the items carefully, and analyzing the data that had been collected. The technique used to analyze the data is descriptive qualitative analysis.

\section{RESULT AND DISCUSSION}

\section{Result}

The data relating to the process of preparing or making the lesson plans for English online learning through Google Classroom are presented in Table 1.

Table 1. Teachers Process in Preparing Lesson Plans for Learning English through Google Classroom

\begin{tabular}{|c|c|c|}
\hline No & Aspects & Steps \\
\hline 1 & Learning & Stating the learning objectives which contains an Audience (A) \\
\hline 2 & Objectives & Stating the learning objectives which contains a Behavior (B) \\
\hline 3 & & Stating the learning objectives which contains a Condition (C) \\
\hline 4 & & Stating the learning objectives which contains a Degree of Attainment (D) \\
\hline 5 & & Relating the learning objectives to the core competency \\
\hline 6 & & Relating the learning objectives to the basic competency \\
\hline 7 & Learning & Organizing the learning materials based on the learning indicators \\
\hline 8 & Materials & Arranging the learning materials based on the learning indicators \\
\hline 9 & & Developing the learning materials into a theme and sub-themes \\
\hline 10 & Learning & Organizing the learning activities based on the learning materials \\
\hline 11 & Activities & Organizing the learning activities based on the learning methods and techniques \\
\hline 12 & Learning & Selecting learning media based on the learning objectives \\
\hline 13 & Media and & Selecting the learning sources based on the learning objectives \\
\hline 14 & Sources & Selecting the learning media based on the learning activities \\
\hline 15 & & Selecting the learning sources based on the learning materials \\
\hline 16 & & Selecting learning media based on the learning methods/techniques \\
\hline 17 & & Selecting learning sources based on the learning methods/techniques \\
\hline 18 & Learning & Selecting the assessment types based on the learning objectives \\
\hline 19 & Assessment & Selecting the assessment techniques based on the learning objectives \\
\hline 20 & & Selecting the assessment types and techniques suitable for an online learning platform \\
\hline
\end{tabular}

As the five aspects of a lesson plan were used as the grand theory for the instrument, the analysis regarding the process in preparing or making the lesson plans made by the teacher was also viewed from the five aspects. The results indicated that the teacher firstly decided and stated the learning objectives that wanted to be achieved through the lessons. The guideline in Curriculum 2013 states that learning objectives need to cover four elements, including audience, behavior, condition, and degree of attainment. The results showed that the teacher already followed the guideline by taking the elements into account. The following explanation shows the parts of the lesson plans that already reflected the guideline. Besides providing learning objectives in the lesson plans, the teacher was also asked whether or not the learning objectives had been linked to the core and basic competencies. Based on the results explained beforehand, it can be seen that the teacher had linked the learning objectives to the competencies expected from the students. 
After stating and providing the learning objectives, the teacher also developed and arranged learning materials that were going to be used in the lessons. It is important to note that learning materials are crucial in both the lesson plans and the instruction as they are used to provide the information related to the topics being learned. The results of the study indicated that the teacher had developed and organized learning materials that were made about the learning indicators. After the materials had been arranged to reflect the indicators, the teacher then organized them into themes and subthemes for easier delivery in the learning process. Next, the teacher also organized the activities that were going to be used in the learning process, which was made concerning the learning materials and techniques or methods of teaching. Including learning activities in the lesson plans are important so that the teacher can be guided about what to do during the lessons. The teacher had conducted the activities in the lesson plan, starting from pre-activities, main activities, and post-activity.

The results also indicated that the teacher also prepared and made the lesson plans by taking the learning media and sources, the fourth aspect, into account. Including this aspect in the lesson plans is important so that the teacher knows and is reminded about what tools and sources need to be prepared to conduct the lessons. The results showed that the teacher selected the learning media and sources by the learning objectives and activities along with the learning methods or techniques. Finally, after organizing the lesson plans from the objectives until the learning media and resources, the teacher proceeded to plan, organize, and make the assessment that was going to be conducted to measure the students' learning outcome. This way, the teacher could decide and judge how well the students have progressed and what improvements are needed to better achieve the learning objectives. There are some types of assessment, including formative, summative, and criterion-referenced assessments. The results indicated that the teacher had selected the assessment type and technique in response to the learning objectives. Besides that, the assessment type and technique were also selected to be suitable for the process of learning that was conducted online through Google Classroom.

Based on the findings and data analysis, several steps were taken by the teacher in preparing or making the lesson plans to teach English to the senior high school students in the context of online learning during the pandemic. The steps taken by the teacher are: asserting the learning objectives along with the audience, asserting the learning objectives along with the behaviour expected from the audience, which in this case were the senior high school students, asserting the learning objectives along with the condition, asserting the learning objectives along with a degree of attainment, connecting the learning objectives to the core competency, linking the learning objectives to the basic competency, developing learning materials that reflected the learning indicators, arranging learning materials that reflected the learning indicators, organizing the learning materials into a theme and subthemes, creating learning activities that reflected the learning materials, creating learning activities that reflected the learning methods and techniques, choosing learning media that reflected the learning objectives, picking learning sources that reflected the learning objectives, picking learning media that reflected the learning activities, choosing learning sources that reflected the learning materials, picking learning media that reflected the learning methods/techniques, choosing learning sources that reflected the learning methods/techniques, picking assessment types that reflected the learning objectives, choosing assessment techniques that reflected the learning objectives, picking assessment types and techniques suitable for online learning platform. The data relating to the difficulties that the teacher faced in preparing or making the lesson plans are shown in Table 2.

Table 2. The English Teachers' Difficulties in Preparing Lesson Plans through Google Classroom

\begin{tabular}{|c|c|c|c|}
\hline No & Aspect & Steps & $\begin{array}{l}\text { Difficulties } \\
\text { (Yes or No) }\end{array}$ \\
\hline 1 & Learning & Stating the learning objectives which contains an Audience (A) & Yes \\
\hline 2 & Objectives & Stating the learning objectives which contains a Behavior (B) & No \\
\hline 3 & & Stating the learning objectives which contains a Condition (C) & No \\
\hline 4 & & $\begin{array}{l}\text { Stating the learning objectives which contains a Degree of } \\
\text { Attainment (D) }\end{array}$ & No \\
\hline 5 & & Relating the learning objectives to the core competency & No \\
\hline 6 & & Relating the learning objectives to the basic competency & No \\
\hline 7 & Learning & Organizing the learning materials based on the learning indicators & No \\
\hline 8 & Materials & Arranging the learning materials based on the learning indicators & No \\
\hline 9 & & Developing the learning materials into a theme and sub-themes & No \\
\hline 10 & Learning & Organizing the learning activities based on the learning materials & No \\
\hline 11 & Activities & $\begin{array}{l}\text { Organizing the learning activities based on the learning methods and } \\
\text { techniques }\end{array}$ & No \\
\hline 12 & Learning Media & Selecting learning media based on the learning objectives & No \\
\hline 13 & and Sources & Selecting the learning sources based on the learning objectives & No \\
\hline 14 & & Selecting the learning media based on the learning activities & No \\
\hline 15 & & Selecting the learning sources based on the learning materials & No \\
\hline
\end{tabular}




\begin{tabular}{|c|c|c|c|}
\hline No & Aspect & Steps & $\begin{array}{l}\text { Difficulties } \\
\text { (Yes or No) }\end{array}$ \\
\hline 16 & & Selecting learning media based on the learning methods/techniques & No \\
\hline 17 & & $\begin{array}{l}\text { Selecting learning sources based on the learning } \\
\text { methods/techniques }\end{array}$ & No \\
\hline 18 & Learning & Selecting the assessment types based on the learning objectives & No \\
\hline 19 & Assessment & $\begin{array}{l}\text { Selecting the assessment techniques based on the learning } \\
\text { objectives }\end{array}$ & No \\
\hline 20 & & $\begin{array}{l}\text { Selecting the assessment types and techniques suitable for the online } \\
\text { learning platform }\end{array}$ & No \\
\hline
\end{tabular}

The data regarding the difficulties that the teacher faced in preparing or making the lesson plans to teach English through Google Classroom were collected through the second questionnaire. The data revealed that the teacher only mentioned one difficulty which was relating to asserting learning objectives that contain the audience. This became an issue as the teacher stated that the internet connection was often trouble and there was limited time in conducting the lesson, thus having the students as the audience in the learning objectives became difficult. Thus, it can be said that there was only one difficulty that the teacher faced in preparing or making the lesson plans, which was related to the learning objectives.

\section{Discussion}

In preparing or making the lesson plans, the teacher should conduct all the steps related to the instrument (Kubilinskiene \& Dagiene, 2010; Mauliate et al., 2019). As the results indicated that the lesson plans developed by the teacher had reflected the aspects and were integrated by the technology used (Google Classroom). It can be interpreted that the lesson plan made by the teacher is an applicable lesson plan for online learning (Indah, 2020; Luciana, 2020; Wulandari, 2020). This is supported by research state that in creating a lesson plan, teachers need to consider six main elements, including the learning indicators, objectives, activities, materials, instructional media, and assessment (Iqbal et al., 2021; Raynesa, 2019; Utami et al., 2021). Indicators are made with regards to the learning objectives, revealing the skills that are expected from the students after the learning process. Therefore, indicators need to be measurable. As students are the ones who are studying, objectives describe the things and skills that the students need to possess by the end of the learning process as the results of the instructions (BinHady \& Abdulsafi, 2019; Iqbal et al., 2021; Utami et al., 2021). There are four types of learning objectives, which include knowledge, intellectual, motor skill, and attitude. In the knowledge objective, the students are expected to have memories and understanding of certain topics and information and can recall them when being needed (Cura et al., 2020; Lauc et al., 2020; Tamboto et al., 2021). The skills expected from the knowledge aspect include being able to list, describe, state, and recognize something. Then, in the intellectual aspect, the students are expected to not only memorize or understand but also use the concept in the real world (Hofmann \& Müller, 2021; Kerr \& Wilkinson, 2006). It includes the ability to classify, use, and solve something. Thirdly, in the motor skill aspect, students are expected to develop motoric ability which enables them to move their muscles and perform something, such as being able to execute and perform (Annisa \& Sutapa, 2019; Cllaudia et al., 2018; Lestari \& Ratnaningsih, 2016). Finally, regarding the attitude, students are expected to have particular beliefs that enable them to act properly. The suggested action verb for this domain is chosen. As all of these aspects are expected from the students, they need to be incorporated into the lesson plans through the use of the action verbs in the activities.

The activities in the classroom will make the Learning process successful if the teachers accommodated the classroom activities well (Khamparia \& Pandey, 2017; Raynesa, 2019; Tjalla et al., 2017). Most of the teachers need a lot of time in designing the best and most effective activities for each topic to make it relevant to the objectives being sought (Khalil, 2018; Lemay et al., 2021; Wang \& Tahir, 2020). This indicates that it is not an easy task. In addition, instructional activities also have some criteria that need to be reflected, such as focusing more on the students as part of student-centered learning, motivating the student to learn, helping them to master the target language, allowing them to think critically, integrating the basic skills in English, providing room for feedback and reflection, and many more (Athanases et al., 2020; Sert \& Boynueğri, 2017; Wang \& Tahir, 2020). Materials in the lesson plan also need to be developed thoughtfully for it to reflect the learning objectives and be appropriate for the student's level and needs (Gunawan, 2017; Syafrijal \& Desyandri, 2019). To deliver the learning process effectively in a fun and creative ways, teachers also need to think about the learning media to use (Gunawan, 2017; Iqbal et al., 2021; Kubilinskiene \& Dagiene, 2010). There are three principles of using media that need to be considered. The first one is effectiveness. To be effective, the learning media need to reflect the learning objective for it to be achieved. The second one is practicality, whereas the media also need to be selected carefully and creatively so that it can be used maximally. Finally, the teachers also need to be concerned about the appropriateness of the media (Buchori et al., 2017; Khamparia \& Pandey, 2017; Nuryadi et al., 2020; Udayani et al., 2021). 
After a certain period in the learning process, evaluation is conducted to measure the students' learning progress, which is known as assessment (Maqableh \& Alia, 2021; Mauliate et al., 2019; Tempelaar, 2019). As it examines the students' learning progress, assessment with regards to the learning objectives, materials, and students' grades (Hanifa, 2018; Mutlu, 2020). In the lesson plan, teachers need to develop the assessment instrument and grading system to keep the learning process on track. Regarding the difficulties encountered by the teacher, in general, the teacher mentioned just one difficulty encountered, which is stating the learning objective containing the audience. In this case, the teacher had difficulty with the audience because of the limited time and the unstable internet signal that make the lesson take a long time to start. Based on the aforementioned statement, the teacher should focus on learning objectives determination at the beginning before the lesson plan is developed. In determining the learning objectives, the teachers have to determine the goals of activities, timing, grouping, and resources.

\section{CONCLUSION}

Based on those twenty steps of making the lesson plan for English learning, it can be inferred that the teacher had reflected the five aspects of the lesson plans, related to the instrument used. Thus, it can be concluded that the teacher has been conducted the process of making following the guideline. Moreover, the difficulty faced by the teacher is related to the learning objective in preparing the lesson plan that includes the audience. It is a simple and efficient lesson plan, which cope 5 data of a good lesson plan, which include the learning objectives, media, sources, activities, materials, and assessment. Regarding Google Classroom, the teacher can explore its use so that it can be maximally used during this online learning, so that it can support the students' flexibility in learning, and they can learn through self-directed learning outside of the classroom.

\section{REFERENCES}

Al-Maroof, R. A. S., \& Al-Emran, M. (2018). Students Acceptance of Google Classroom: An Exploratory Study using PLS-SEM Approach. International Journal of Emerging Technologies in Learning (IJET), 13(06), 112-123. https://doi.org/10.3991/ijet.v13i06.8275.

Albashtawi, A., Ham Albashtawi, A. H., \& Bataineh, A. (2020). The effectiveness of google classroom among EFL students in Jordan: An innovative teaching and learning online platform. International Journal of Emerging Technologies in Learning, 15(11), 78-88. https://doi.org/10.3991/IJET.V15I11.12865.

Amrina, R., \& Sundari, H. (2021). Learning from Home Environment: Academic Writing Course for EFL Undergraduates through Google Classroom Application. Studies in English Language and Education, 8(2), 710-725. https://doi.org/10.24815/siele.v8i2.18374.

Annisa, A., \& Sutapa, P. (2019). The Implementation of Nature-based Learning Models to Improve Children's Motor Skills. Jurnal Obsesi: Jurnal Pendidikan Anak Usia Dini, 3(1), 170. https://doi.org/10.31004/obsesi.v3i1.140.

Arkiang, F. (2021). Analisis Pembelajaran Daring Selama Pandemi Covid-19 Di Daerah 3T (Nusa Tenggara Timur). Jurnal Pendidikan, 12(1), 57-64. https://doi.org/10.31258/jp.12.1.57-64.

Athanases, S. Z., Sanchez, S. L., \& Martin, L. M. (2020). Saturate, situate, synthesize: Fostering preservice teachers' conceptual and practical knowledge for learning to lead class discussion. Teaching and Teacher Education, 88, 102970. https://doi.org/10.1016/j.tate.2019.102970.

Atmojo, A. E. P., \& Nugroho, A. (2020). EFL Classes Must Go Online! Teaching Activities and Challenges during COVID-19 Pandemic in Indonesia. Register Journal, 3(1). https://doi.org/10.18326/rgt.v13i1.49-76.

Atmojo, Arief Eko Priyo, \& Nugroho, A. (2020). EFL classes must go online! Teaching activities and challenges during COVID-19 pandemic in Indonesia. Register Journal, 13(1), 49-76. https://doi.org/10.18326/rgt.v13i1.49-76.

Basri, H. (2018). Strategi Belajar Kosakata Bahasa Inggris (English Vocabulary). Strategi Belajar Kosakata Bahasa Inggris (English Vocabulary, 11(2), 432-444. https://doi.org/10.19105/ojbs.v8i2.468.

Bin-Hady, W. R. A., \& Abdulsafi, A. S. T. (2019). How Can I Prepare an Ideal Lesson Plan? SSRN Electronic Journal, 7(4). https://doi.org/10.2139/ssrn.3434031.

Buchori, Rahmawati, S., \& Wardani, S. (2017). The Development of A Learning Media for Visualizing the Pancasila Values Based on Information and Communication Technology. Jurnal Cakrawala Pendidikan, 36(3), 502-521. https://doi.org/10.21831/cp.v36i3.12748.

Cllaudia, E. S., Widiastuti, A. A., \& Kurniawan, M. (2018). Origami Game for Improving Fine Motor Skills for Children 4-5 Years Old in Gang Buaya Village in Salatiga. Jurnal Obsesi : Jurnal Pendidikan Anak Usia Dini, 2(2). https://doi.org/10.31004/obsesi.v2i2.97.

Cura, Ş. Ü., Kocatepe, V., Yıldırım, D., Küçükakgün, H., Atay, S., \& Ünver, V. (2020). Examining Knowledge, Skill, Stress, Satisfaction, and Self-Confidence Levels of Nursing Students in Three Different Simulation 
Modalities. Asian Nursing Research, 14(3). https://doi.org/10.1016/j.anr.2020.07.001.

Dang, T. N. Y. (2021). English for Vocational Purposes: Language uses in trades education, Averil Coxhead, Jean Parkinson, James Mackay, Emma McLaughlin, 1st Edition, Routledge, Taylor \& Francis Group, London (2019). English for Specific Purposes, 63. https://doi.org/10.1016/j.esp.2021.04.002.

Gonzalves, L. (2021). Development of coping skills in L2 adult English learners with emergent print literacy. Journal of Second Language Writing, 51. https://doi.org/10.1016/j.jslw.2021.100790.

Gunawan, I. (2017). Indonesian Curriculum 2013: Instructional Management, Obstacles Faced by Teachers in Implementation and the Way Forward. Proceedings of the 3rd International Conference on Education and Training (ICET 2017), 56-63. https://doi.org/10.2991/icet-17.2017.9.

Guswara, A. M. (2020). The Contribution of Google Classroom Application and Motivation to The Learning Outcomes of Web Programming. Educational Technology, 4(4), 1-9. https://doi.org/10.23887/jet.v4i4.29896.

Haka, N. B., Anggita, L., Anggoro, B. S., \& Hamid, A. (2020). Pengaruh Blended Learning Berbantukan Google Classroom Terhadap Keterampilan Berpikir Kreatif Dan Kemandirian Belajar Peserta Didik. Edu Sains Jurnal Pendidikan Sains \& Matematika. https://doi.org/10.23971/eds.v8i1.1806.

Hanifa, R. (2018). EFL Published Materials: An Evaluation of English Textbooks for Junior High School in Indonesia. Advances in Language and Literary Studies, 9(2), 166. https://doi.org/10.7575/aiac.alls.v.9n.2p.166.

Harjanto, A. S., \& Sumarni, S. (2019). Teachers' Experiences On The Use Of Google. 3rd English Language and Literature International Conference (ELLiC) Proceedings - (ELLiC, 3, 172-178.

Ho, Y.-Y. C. (2020). Communicative language teaching and English as a foreign language undergraduates' communicative competence in Tourism English. Journal of Hospitality, Leisure, Sport \& Tourism Education, 27. https://doi.org/10.1016/j.jhlste.2020.100271.

Hofmann, V., \& Müller, C. M. (2021). Language skills and social contact among students with intellectual disabilities in special needs schools. Learning, Culture, and Social Interaction, 30. https://doi.org/10.1016/j.lcsi.2021.100534.

Indah, P. (2020). Development of HOTS (High Order Thinking Skill) Oriented Learning Through Discovery Learning Model to Increase The Critical Thinking Skill of High School Students. International Journal of Chemistry Education Research, 3(3). https://doi.org/10.20885/ijcer.vol4.iss1.art4

Iqbal, M. H., Siddiqie, S. A., \& Mazid, M. A. (2021). Rethinking theories of lesson plan for effective teaching and learning. Social Sciences \& Humanities Open, 4(1). https://doi.org/10.1016/j.ssaho.2021.100172.

Kadafi, A., Alfaiz, A., Ramli, M., Asri, D. N., \& Finayanti, J. (2021). The impact of islamic counseling intervention towards students' mindfulness and anxiety during the covid-19 pandemic. Islamic Guidance and Counseling Journal, 4(1), 55-66. https://doi.org/10.25217/igcj.v4i1.1018.

Kao, C.-W. (2020). The effect of a digital game-based learning task on the acquisition of the English Article System. System, 95. https://doi.org/10.1016/j.system.2020.102373.

Kerr, D., \& Wilkinson, H. (2006). Responding to pain needs of people with a learning disability/intellectual disability and dementia: What are the key lessons. International Journal on Disability and Human Development, 5(1). https://doi.org/10.1515/IJDHD.2006.5.1.69.

Khalil, Z. M. (2018). EFL Students' Perceptions towards Using Google Docs and Google Classroom as Online Collaborative Tools in Learning Grammar. Applied Linguistics Research Journal, 2(2), 33-48. https://doi.org/10.14744/alrj.2018.47955.

Khamparia, A., \& Pandey, B. (2017). Impact of interactive multimedia in E-learning technologies: Role of multimedia in E-learning. Enhancing Academic Research With Knowledge Management Principles, April, 199-227. https://doi.org/10.4018/978-1-5225-2489-2.ch007.

Kubilinskiene, S., \& Dagiene, V. (2010). Technology-Based Lesson Plans: Preparation and Description. Informatics in Education, 9(2), 217-228. https://doi.org/10.15388/infedu.2010.15.

Kumar, J. A., Bervell, B., \& Osman, S. (2020). Google classroom : insights from Malaysian higher education students ' and instructors ' experiences. Education and Information Technologies, 25. https://doi.org/10.1007/s10639-020-10163-X.

Kurniawati, M., Santanapurba, H., \& Kusumawati, E. (2019). Penerapan Blended Learning Menggunakan Model Flipped Classroom Berbantuan Google Classroom Dalam Pembelajaran Matematika Smp. EDU-MAT: Jurnal Pendidikan Matematika, 7(1), 8-19. https://doi.org/10.20527/edumat.v7i1.6827.

Latifa, I. S. (2017). The Analysis of Teachers' Lesson Plan through Behavioral Objectives Theory. Advances in Social Science, Education, and Humanities Research (ASSEHR), 82(1), 6-11. https://doi.org/10.2991/conaplin-16.2017.2.

Lauc, T., Jagodić, G. K., \& Bistrović, J. (2020). Effects of Multimedia Instructional Message on Motivation and Academic Performance of Elementary School Students in Croatia. International Journal of Instruction, 13(4), 491-508. https://doi.org/10.29333/iji.2020.13431a. 
Lemay, D. J., Bazelais, P., \& Doleck, T. (2021). Transition to online learning during the COVID-19 pandemic. Computers in Human Behavior Reports, 4, 100130. https://doi.org/10.1016/j.chbr.2021.100130.

Lestari, I., \& Ratnaningsih, T. (2016). The Effects of Modified Games on the Development of Gross Motor Skill in Preschoolers. International Journal of Evaluation and Research in Education (IJERE), 5(3), 216-220. https://doi.org/10.11591/ijere.v5i3.4542.

Liza, K., \& Andriyanti, E. (2020). Digital Literacy Scale of English Pre-Service Teachers and Their Perceived Readiness toward the Application of Digital Technologies. Journal of Education and Learning (EduLearn), 14(1), 74-79. https://doi.org/10.11591/edulearn.v14i1.13925.

Luciana, N. L. R. (2020). Teachers' Readiness in Inserting the 21st Century Skills in the Lesson Plan in Teaching English. Jurnal Pendidikan Dan Pengajaran, 53(2), 168. https://doi.org/10.23887/jpp.v53i2.26406.

Maharani, Y. S. (2015). Efektivitas Multimedia Pembelajaran Interaktif Berbasis Kurikulum 2013. Indonesian Journal of Curriculum and Educational Technology Studies, 3(1), 31-40. https://doi.org/10.15294/ijcets.v3i1.8683.

Mahitsa, M., \& Mahardini, A. (2020). Analisis Situasi Penggunaan Google Classroom pada Pembelajaran Daring Fisika. Jurnal Pendidikan FIsika, VIII(2), 215-224. https://doi.org/10.24127/jpf.v8i2.3102 ANALISIS.

Maqableh, M., \& Alia, M. (2021). Evaluation online learning of undergraduate students under lockdown amidst COVID-19 Pandemic: The online learning experience and students' satisfaction. Children and Youth Services Review, 128(1). https://doi.org/10.1016/j.childyouth.2021.106160.

Mauliate, H. D., Rahmat, A., \& Wachidah, S. (2019). Evaluation the Lesson Plan of English Language Learning in Junior High School, Seraphine Bakti Utama West Jakarta. International Journal of Scientific Research and Management, 7(07), 1078-1086. https://doi.org/10.18535/ijsrm/v7i7.el02.

Megawati, \& Utami. (2020). English Learning with Powtoon Animation Video. Journal of Education Technology, 4(2), 110. https://doi.org/10.23887/jet.v4i2.25096.

Mokshein, S. E., Ishak, H., \& Ahmad, H. (2019). the Use of Rasch Measurement Model in English Testing. Jurnal Cakrawala Pendidikan, 38(1), 16-32. https://doi.org/10.21831/cp.v38i1.22750.

Mpungose, C. B. (2020). Emergent transition from face-to-face to online learning in a South African University in the context of the Coronavirus pandemic. Humanities and Social Sciences Communications 2020 7:1, 7(1), 1-9. https://doi.org/10.1057/s41599-020-00603-X.

Mutlu, A. (2020). Evaluation of students' scientific process skills through reflective worksheets in the inquirybased learning environments. Reflective Practice, 21(2). https://doi.org/10.1080/14623943.2020.1736999.

Nartiningrum, N. (2020). Online Learning amidst Global Pandemic : EFL Students' Challenge, Suggestions, and Needed Materials. ENGLISH FRANCA : Academic Journal of English Language and Education, 4(2), 115-140. https://doi.org/10.29240/ef.v4i2.1494.

Nugroho, A., Ilmiani, D., \& Rekha, A. (2021). EFL Teachers' Challenges and Insights of Online Teaching amidst Global Pandemic. Metathesis: Journal of English Language, Literature, and Teaching, 4(3), 277. https://doi.org/10.31002/metathesis.v4i3.3195.

Nuryadi, N., Kurniawan, L., \& Kholifa, I. (2020). Developing mobile learning based on ethnomathematics viewed from adaptive e-learning: Study of two dimensions geometry on Yogyakarta palace's chariot. International Journal of Education and Learning, 2(1), 32-41. https://doi.org/10.31763/ijele.v2i1.85.

Raynesa. (2019). Lesson Planning in EFL Classroom: A Case Study in Lesson Plan Preparation and Implementation. Wiralodra English Journal, 3(2), 367-375. https://doi.org/10.31943/wej.v3i2.67.

Rohita, R., Fitria, N., Bustan, R., \& Haryadi, D. (2018). Teacher's Understanding of the Scientific Approach in the 2013 Curriculum for Early Childhood Education. Jurnal Obsesi : Jurnal Pendidikan Anak Usia Dini, 2(2), 235. https://doi.org/10.31004/obsesi.v2i2.105.

Santosa, F. H., Negara, H. R. P., \& Samsul Bahri. (2020). Efektivitas Pembelajaran Google Classroom Terhadap Kemampuan Penalaran Matematis Siswa. Jurnal Pemikiran Dan Penelitian Pendidikan Matematika (JP3M), 3(1), 62-70. https://doi.org/10.36765/jp3m.v3i1.254.

Sari, P. P. (2018). An Analysis of Lesson Plan in The 2013 Curriculum Made by English Teacher. International Conference on English Language Teaching, 1-12.

Sert, N., \& Boynueğri, E. (2017). Digital technology use by the students and English teachers and self-directed language learning. World Journal on Educational Technology: Current Issues, 9(1), 24. https://doi.org/10.18844/wjet.v9i1.993.

Singh, C. K. S., Singh, T. S. M., Abdullah, N. Y., Moneyam, S., Ismail, M. R., Tek, E., Karupayah, T., Chenderan, K., Singh, M. K. R., \& Singh, J. K. S. (2020). Rethinking English language teaching through Telegram, Whatsapp, Google classroom, and Zoom. Systematic Reviews in Pharmacy, 11(11), 45-54. https://doi.org/10.31838/srp.2020.11.9.

Sugiarto, A. (2020). Dampak Positif Pembelajaran Online Dalam Sistem Pendidikan Keperawatan Pasca Pandemi Covid 19. Jurnal Perawat Indonesia, 4(3), 432. https://doi.org/10.32584/jpi.v4i3.555. 
Suhery, S., Putra, T. J., \& Jasmalinda, J. (2020). Sosialisasi Penggunaan Aplikasi Zoom Meeting Dan Google Classroom Pada Guru Di Sdn 17 Mata Air Padang Selatan. Jurnal Inovasi Penelitian, 1(3), 129-132. https://doi.org/10.47492/jip.v1i3.90.

Sundayana, W. (2015). Readiness and competence of senior high school English teachers to implement Curriculum 2013. Indonesian Journal of Applied Linguistics, 5(1), 29-36. https://doi.org/10.17509/ijal.v5i1.828.

Susilowati, S., Sajidan, S., \& Ramli, M. (2018). Keefektifan perangkat pembelajaran berbasis inquiry lesson untuk meningkatkan keterampilan berpikir kritis siswa. Jurnal Penelitian Dan Evaluasi Pendidikan, 22(1), 4960. https://doi.org/10.21831/pep.v22i1.17836.

Syafrijal, \& Desyandri. (2019). Development Of Integrated Thematic Teaching Materials With Project Based Learning Models In Class IV of Primary School. International Journal of Educational Dynamics/IJEDS, 1(2), 87-92. https://doi.org/10.24036/ijeds.v1i2.110.

Tamboto, H., Tambingon, H. N., Lengkong, J. S. ., \& Rotty, V. N. J. (2021). The Involvement of Students' Parents in Organizing the Learning from Home at Elementary Schools in Tomohon City. Asia Pacific Journal of Management and Education, 4(1), 35-51. https://doi.org/10.32535/apjme.v4i1.1044.

Tempelaar, D. (2019). Assessment \& Evaluation in Higher Education Supporting the less-adaptive student: The role of learning analytics, formative assessment, and blended learning. Assessment and Evaluation in Higher Education, 45(4). https://doi.org/10.1080/02602938.2019.1677855.

Tjalla, M., Akil, M., Hamra, A., \& Haryanto. (2017). The analysis of EFL students' needs for writing materials development. International Journal of Science and Research, 6(8), 313-317. https://doi.org/10.21275/ART20175922.

Udayani, N. K. R. T. K., Wibawa, I. M. C., \& Rati, N. W. (2021). Development Of E-Comic Learning Media On The Topic Of The Human Digestive System. Journal of Education Technology, 5(3), 472-481. https://doi.org/10.23887/jet.v5i3.34732.

Utami, N. W., Sayuti, S. A., \& Jailani, J. (2021). Indigenous artifacts from remote areas were used to design a lesson plan for preservice math teachers regarding sustainable education. Heliyon, 7(3). https://doi.org/10.1016/j.heliyon.2021.e06417.

Wahyuningtyas, R., \& Sulasmono, B. S. (2020). Pentingnya Media dalam Pembelajaran Guna Meningkatkan Hasil Belajar di Sekolah Dasar. Edukatif: Jurnal Ilmu Pendidikan, 2(1), 23-27. https://doi.org/10.31004/edukatif.v2i1.77.

Wang, A. I., \& Tahir, R. (2020). The effect of using Kahoot! for learning - A literature review. Computers and Education, 149(January), 103818. https://doi.org/10.1016/j.compedu.2020.103818.

Winarti, Hairida, \& Lestari, I. (2021). Deskripsi Kemampuan Guru Membuat Soal Berdasarkan pada Kurikulum 2013 di Sekolah Menengah Atas Kabupaten Landak. Jurnal Ilmiah Wahana Pendidikan, 7(2), 108-115. https://doi.org/10.5281/zenodo.3737983.

Wulandari, A. (2020). Implementation of the 2013 Curriculum Based on a Scientific Approach (Case Study at SD Cluster II Kintamani). International Journal of Elementary Education, 4(3), 422. https://doi.org/10.23887/ijee.v4i3.28172.

Yulia. (2020). Online Learning to Prevent the Spread of Pandemic Corona Virus in Indonesia. ETERNAL (English Teaching Journal), 11(1). https://doi.org/10.26877/eternal.v11i1.6068. 